\title{
THE IMPACT OF AN EDUCATIONAL INSTITUTION ON DEVELOPMENT OF HEALTHY LIFESTYLE SKILLS FOR PREVENTION OF OBESITY IN ADOLESCENTS
}

DOI: $10.36740 /$ WLek202005126

\author{
Heorhii M. Danylenko ${ }^{1,2}$, Zhanna V. Sotnikova-Meleshkina ${ }^{1,2}$, Vladyslav A. Smiianov ${ }^{3}$ \\ "STATE INSTITUTION "INSTITUTE OF CHILDREN AND ADOLESCENTS HEALTH CARE OF NATIONAL ACADEMY OF MEDICAL SCIENCES OF UKRAINE", \\ KHARKIV, UKRAINE \\ 2V.N. KARAZIN KHARKIV NATIONAL UNIVERSITY, KHARKIV, UKRAINE \\ 3SUMY STATE UNIVERSITY, SUMY, UKRAINE
}

\begin{abstract}
The aim: To determine that nature of perception of an educational institution has on degree of risk as to development of bad habits in eating and daily routine. Materials and methods: We have conducted surveys among 1015 students of educational institutions, residing in a large industrial center through special questionnaire was developed by SI «ICAHC NAMS». According to answer to the question about their attitude towards school, schoolchildren have been divided into 6 groups.

Results: Studying the health-shaping behavior of children has shown the greatest regularity of engagement in sports activities among students of the 1st group. Schoolchildren of the 4th group were characterized by the risk of development of obesity, due to the highest (among the other groups) level of consumption of chips, crackers, street food, sparkling water, against insufficient acquirement of key sources of protein and vitamins. The same groups also differed in self-esteem of their own health and perception of school environment.

Conclusions: The most safe group as to development of obesity and other diseases has been the 1st group, students of which attended an educational institution with pleasure and had a high level of physical activity and had certain eating habits. Children of the 4th group with indifferent attitude towards any occupation should be included into the risk group. Outstanding remains the issue in-depth study of prevalence of healthy lifestyle skills and bad habits among various gender groups of adolescents.
\end{abstract}

KEY WORDS: Healthy lifestyle, Health Education, Physical activity, Feeding Behavior, Prevention of obesity

\section{INTRODUCTION}

Preservation and strengthening of health of children and adolescents is one of the most important tasks in public health area of any country. Bad nutrition, low physical activity, sedentary behavior and smoking are risk factors of chronic diseases, and they are modified and often develop at the beginning of life, in adolescence [1]. High prevalence of childhood obesity is a serious medical and social problem, since excessive fat deposition is associated not only with somatic and endocrine pathology, but also with decrease of cognitive abilities, school performance and future professional achievements [2].

Lower physical activity of adolescents is perceived not only as bad physical shape, but is also associated with significant somatic and psychological issues in adolescents [3]. On the contrary, multi-component intervention as to healthy nutrition and physical activity contribute to improvement of memory, cognitive processes and overall academic performance [2]. In industrially developed society, increase of physical activity adds more than 600 dollars, daily extra portion of fruits and vegetables - 115 dollars, and not smoking -563 dollars per week, which in turn are necessary for maintaining a certain level of life satisfaction [4].
Expansion of knowledge on nature of nutrition of children at various age enables one to improve eating habits and lifestyle, and influence prevalence of non-infectious diseases associated with obesity, not only in adolescence but in more mature age [5].

Attitude towards one's own health, development of rational eating and daily routine skills, abandonment of bad habits are significant factors that impact state of health of a growing generation. Healthy lifestyle skills are developed in a social environment where a child grows up. One of the centers of such influence are educational institutions, which on one hand are one of social determinants of health, and on the other hand are an effective platform for preventive measures [6-9].

Improved understanding of how unhealthy behavior emerges and develops in childhood can contribute to more effective approaches to prevention of non-infectious diseases, which in turn will promote improvement of educational process and its efficiency $[1,2,10]$.

\section{THE AIM}

The aim of research was to determine impact that emotional perception of an educational institution by adolescents has on degree of risk as to development of bad habits in eating and daily routine. 


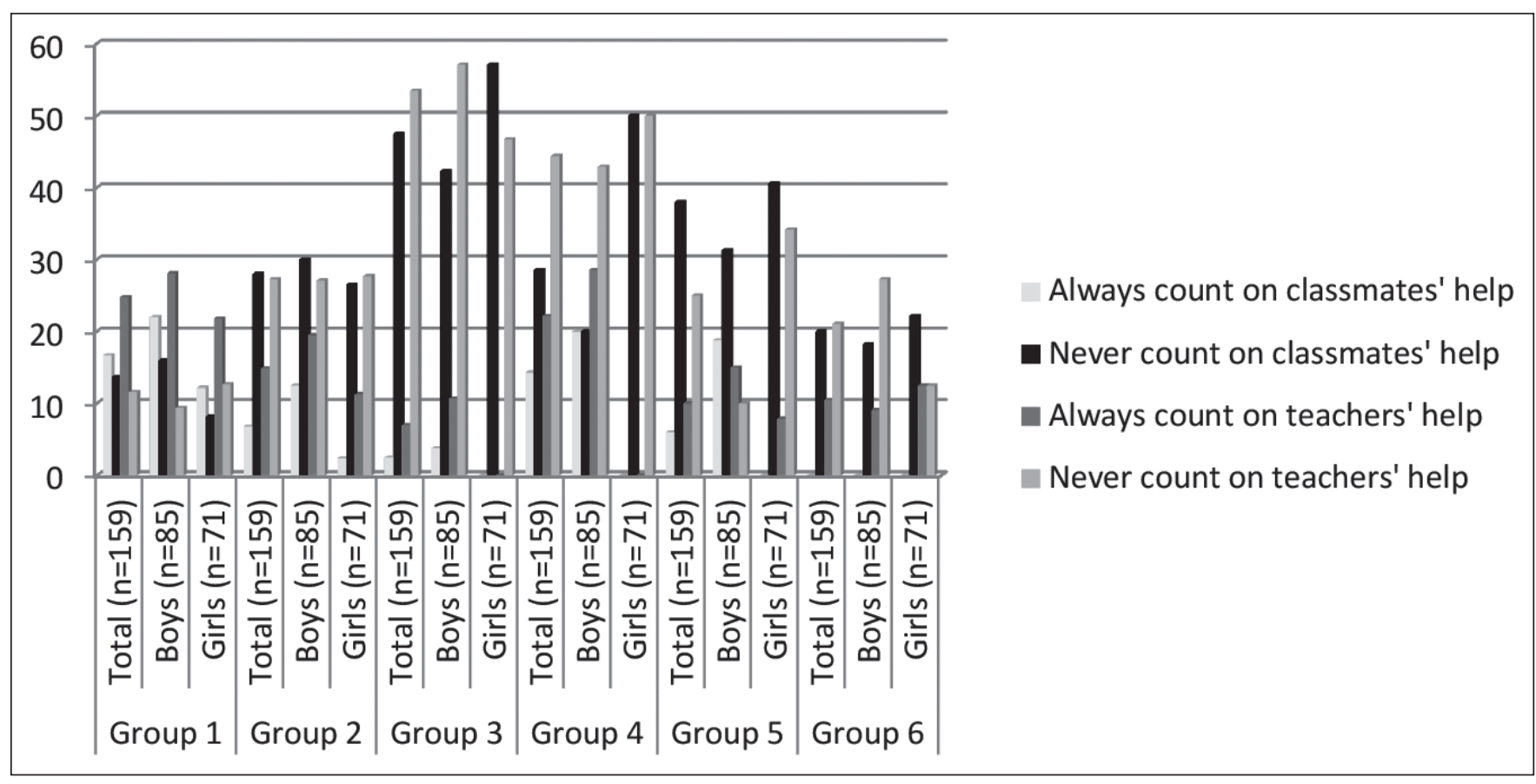

Figure 1. Analysis of degree of counting on help from school environment, \%

\section{MATERIALS AND METHODS}

We have conducted surveys among 1015 ninth grade students of educational institutions, residing in a large industrial center. Special questionnaire was developed by SI «ICAHC NAMS», containing blocks of questions regarding attitude towards school, relationship with parents, friends, teachers, daily routine aspects, frequency of food consumption, presence of bad habits. Depending on the answers to questions as to their attitude towards school, students have been divided into 6 groups, namely: group 1 - students who attended educational institution with pleasure - $15.6 \%(n=159)$; group 2 - students who perceived studying in educational institution as their duty - $69.9 \%(n=701)$; group 3 - students who were depressed by attending school - $4.92 \%$ $(n=50)$; group 4 - students with indifferent attitude towards any occupation $-1.2 \%(n=13)$; group $5-$ students with undecided attitude towards school $-6.89 \%(n=70)$; group 6 - students whose attitude towards school is colored by their personality $-2.1 \%(n=22)$.

The study was carried out in accordance with the national norm of bioethics and statements of Helsinki declaration (1975, version of 2013) for medical research involving human subjects, including research on identifiable human material and data. For analysis of respondents' answers, methods of mathematical statistics have been used, allowing us to establish statistically significant discrepancies between groups of respondents through analysis of variance and t-test features of "MS Excel" and "SPSS" software suites.

\section{RESULTS}

School in not only a part of environment and an institution where children are engaged in learning activity for a significant part of their day, but also a powerful factor in development of behavior in society and of lifestyle $[7,8]$. For that reason, we have assessed the degree to which the adolescents, depending on their attitude towards school, counted on help of their teachers and classmates (fig.1).

It has been established that the most comfortable emotional «conditions of being» were characteristic for adolescents of group 1, who in $16.7 \%$ of cases always counted on help from classmates, and in $24.8 \%$ of cases - on help from teachers, which is veraciously higher than in groups 3,5 and $6(\mathrm{p}<0.05-0.01)$.

Important indicators of level of development of healthy lifestyle skills are eating behavior and physical activity. For effective prevention of obesity, it is necessary to combine limited foodstuffs with high number of calories, sufficient physical activity and consumption of healthful foodstuffs $[2,11,12]$.

According to the stated aim of research, we have analyzed the part of the questionnaire pertaining to health-shaping behavior, namely: level of physical activity and frequency of consumption of certain foodstuffs.

Of importance is the issue of regularity of students' engagement in sports activities (tab. I). We have established the highest frequency of attending sports activities among students of the first group: almost every day $-50.0 \%$, which is significantly higher than in groups 2,3 and $5(\mathrm{p}<0.05)$

On of the main health-shaping factors is rational eating. In order to assess eating routine and proceeding of key nutrients into an organism, we have analyzed frequency of foodstuff consumption. Analysis of degree of consumption of key foodstuffs and fast food has shown the lowest consumption of such important foodstuffs as fish, meat, and the highest prevalence of "bad" eating habits among students of the 4 th group. So it stands, that the key sources of protein, meat and fish, were not a daily part of a diet of adolescent girls of the 4 th group. 
Table I. Analysis of regularity of engagement in sports activities, $\%$

\begin{tabular}{|c|c|c|c|c|c|c|c|}
\hline Frequency of activities & $\begin{array}{l}\bar{a} \\
\text { 옥 } \\
\text { 은 } \\
\text { 는 }\end{array}$ & $\begin{array}{l}\text { No } \\
\text { 응 } \\
\text { 은 Iㅡ } \\
\text { 드 }\end{array}$ & $\begin{array}{l}m \\
\text { 을 } 0 \\
\text { ㅇํㄴ } \\
\text { 인 }\end{array}$ & 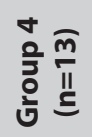 & 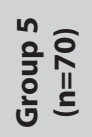 & $\begin{array}{l}0 \\
\text { 을 } \\
\text { 인 } \\
\text { 트 }\end{array}$ & 픈 $\frac{\pi}{0}$ \\
\hline 1. Almost every day & $50.0^{*}$ & $38.8^{*}$ & $32.0^{*}$ & 41.7 & $26.5^{*}$ & 30.0 & 39.1 \\
\hline 2. 4-5 times per week & 17.3 & 19.9 & $14.0^{*}$ & $25.0^{*}$ & $29.4^{*}$ & 0.0 & 19.7 \\
\hline 3. 2-3 times per week & $23.1^{* *}$ & 32.2 & 40.0 & 25.0 & 30.9 & 65.0 & 31.5 \\
\hline 4. No engagement & 9.6 & 9.1 & 14.0 & 8.3 & 13.2 & 5.0 & 9.6 \\
\hline
\end{tabular}

Note: ${ }^{*}-p<0.05$ compared to another group, ${ }^{* *}-p<0.01$ compared to another group

Table II. Analysis of frequency of consumption of street food, $\%$

\begin{tabular}{|c|c|c|c|c|c|c|c|}
\hline Frequency of consumption & $\begin{array}{l}\text { 음 } \\
\text { 을 } \\
\text { 은 트 }\end{array}$ & $\begin{array}{l}N= \\
\text { 을 } \\
\text { 온 }\end{array}$ & $\begin{array}{l}m \\
\text { 을 옹 } \\
\text { 은 으 }\end{array}$ & 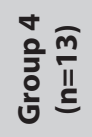 & $\begin{array}{l}\text { n } \\
\text { 을 } \\
\text { 은 } \\
\text { 은 }\end{array}$ & $\begin{array}{l}0 \\
0 \\
\frac{0}{3} \\
\text { N } \\
\text { 는 }\end{array}$ & 휴을 \\
\hline Every day & $3.4^{*}$ & $5.2^{*}$ & $24.5^{*}$ & 27.3 & $7.8^{*}$ & $0.0^{* *}$ & 6.4 \\
\hline 2-3 times per week & 6.7 & 9.8 & 8.2 & 9.1 & 4.7 & 10.0 & 9.1 \\
\hline 1 time per week & 17.5 & 15.2 & $12.2^{*}$ & 9.1 & 12.5 & $0.0^{* *}$ & 14.9 \\
\hline 1 time per month & 30.9 & 27.6 & 24.5 & 45.5 & 26.6 & 30.0 & 27.8 \\
\hline No consumption & $41.6^{*}$ & $42.2^{* *}$ & $30.6^{*}$ & $9.1^{* *}$ & $48.4^{* *}$ & $60.0^{* *}$ & 41.8 \\
\hline
\end{tabular}

Note: ${ }^{*}-p<0.05$ compared to another group, ${ }^{* *}-p<0.01$ compared to another group

Table III. Analysis of frequency of consumption of fresh vegetables, $\%$

\begin{tabular}{|c|c|c|c|c|c|c|c|}
\hline Frequency of consumption & 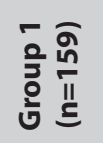 & $\begin{array}{l}\text { N } \\
\text { 을 } \\
\text { 웅 } \\
\text { 는 }\end{array}$ & $\begin{array}{l}m \\
\text { 을 을 } \\
\text { 윤 } \\
\text { 는 }\end{array}$ & 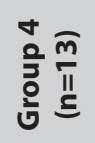 & 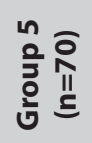 & $\begin{array}{l}0 \\
\stackrel{0}{3} \text { N } \\
\text { 인 }\end{array}$ & 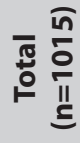 \\
\hline Every day & $74.3^{* *}$ & $59.8^{* *}$ & $56.3^{*}$ & 80.0 & $57.6^{*}$ & $45.0^{*}$ & 66.8 \\
\hline 2-3 times per week & $18.4^{*}$ & $25.9^{*}$ & 25.0 & 20.0 & 30.3 & 40.0 & 24.1 \\
\hline 1 time per week & $5.3^{*}$ & $9.2^{* *}$ & $14.6^{*}$ & $0.0^{* *}$ & $9.1^{*}$ & 5.0 & 5.8 \\
\hline 1 time per month & $0.0^{* *}$ & $2.0^{* *}$ & 4.2 & $0.0^{* *}$ & 1.5 & 5.0 & 1.6 \\
\hline No consumption & 2.0 & $3.2^{* *}$ & $0.0^{* *}$ & $0.0^{* *}$ & 1.5 & 5.0 & 1.7 \\
\hline
\end{tabular}

Note: ${ }^{*}-p<0.05$ compared to another group, ${ }^{* *}-p<0.01$ compared to another group

Chips and crackers were consumed mostly by students of groups 3 and 4 , which is veraciously higher with $3 \mathrm{rd}$ group when compared with the 1 st group $(\mathrm{p}<0.05)$. That being said, eating behavior was somewhat different depending on sex. So it stands, that among girls of the 2nd group, there were more of them who consume chips and crackers 2-3 times per week, compared to groups 4, 5 and $6(\mathrm{p}<0.01)$. Among boys of the 1 st group, the most prevalent is the part representing those who did not consume these foodstuffs at all $-41.6 \%$ ( $<<0.05$ compared to groups 2, 3 and 5)

In the course of overall analysis of the groups, without distributing into subgroups according to sex, it has been established (tab. II) that among students of the 4 th group, there is the highest percent of those who consume street food daily, and the lowest percent of those do not consume it at all (veraciously compared to groups 1, 2, 5 and $6 ; \mathrm{p}<0.01$ ). Such prevalence is the result of boys' contribution: $33.0 \%$ and $0 \%$, respectively. The smallest prevalence of consumption of street food was characteristic for students of the 6th group $(0 \%$ of those who consume it daily, and $60 \%$ did not consume it at all during the last month), but veraciously only compared to groups 3 and $4(\mathrm{p}<0.05-0.01)$.

We have analyzed the frequency of consumption of sparkling water as one of the risk factors of development of obesity. The habit of daily consumption of such drinks is the most characteristic for students of the 4th group - 
moreover, that is so due to boys' contribution (30.0\%), while this habit is absolutely absent in the 6th group regardless of sex. On average, the degree of consumption was the greatest among schoolchildren of groups 2 and 4 , compared to groups 1,5 and $6(\mathrm{p}<0.05)$.

The most prevalent daily consumption of fresh vegetables (tab. III) was among students of the 4 th group $(80.0 \pm 13.3 \%)$, but veraciously only among girls when compared to all the other groups $(\mathrm{p}<0.01)$. Second place by this indicator belongs to the 1st group $(74.3 \pm 3.6) \%$, which is veraciously higher when compared to groups 1,5 and $6(\mathrm{p}<0.01)$ and to group $3(\mathrm{p}<0.05)$.

It is also appropriate to identify such a trait as self-esteem of one's own health and awareness of safety degree of behavior as to development of bad habits.

Percent of students completely satisfied by their health status was veraciously higher in the 1st group when compared to groups 2, 3, 5 and $6(\mathrm{p}<0.05-0.01)$, with the value of $77.8 \pm 3.4 \%$. Students of the 4 th group were dissatisfied with their health status more often than others, while among groups 1, 3 and 6 such a category has not been identified.

\section{DISCUSSION}

Rapid development of new forms of social reality, limitless expansion of information space, symbiosis of real and virtual forms of health-preserving activities have substantially changed not only structure of everyday practices and foundations of health-preserving behavior, but also traditional forms of subjective reactions, cognitive and axiological constants of social behavior, reflexive and unconscious mechanisms and motivations as to preservation of one's own health. In our research, we have implemented a holistic approach as to identification of reasons of obesity, including its connection to nutrition and lifestyle, as well as social and demographical factors [11].

Such researches are fairly common in public health. In that regard, Wadolowska L. and co-authors have been identifying level of development of healthy lifestyle, including the issue of nutrition and motion activity in connection with school education among 464 students aged 11-12 years. It has been proved, that educational work as to healthy lifestyle, rational eating and abandonment of bad eating habits promote decrease in prevalence of obesity [11].

Hamulka J. has performed a complex assessment of cross-behavioral models that cover diet and lifestyle of Polish adolescents [5].

In a Portuguese research, conducted among 5024 adolescents, summary score of healthy lifestyle had been based on physical activity, duration of night's sleep, daily consumption of vegetables and fruits, abandonment of smoking and alcohol, and had been associated with quality of life and self-esteem of health [14].

Improved understanding of how unhealthy behavior happens in specific children during childhood and adolescence can enable development of more effective approaches to prevention [1]. Degree of counting on help from the closest environment can be viewed, on one hand, as one of stress factors which push an adolescent towards development of deviant behavior. On the other hand, relying on trust-based relations with parents, teachers, adults, judging and taking example from them, it is possible to develop necessary habits of healthy lifestyle.

According to results of the researches conducted in Northern England, it has been noted that educational institutions should utilize strategies as to long-term engagement of school employees, schoolchildren and their parents. In order to provide sustainability, it has been noted that the programs should be integrated in long-term curricula and school policy, with steady support of principals and staff [15].

Key components of safe nutrition model for children and adolescents, which according to modern views should be combined with prevention of obesity, include frequency of eating, choice of foodstuffs in a daily ration, and adherence to norms pertaining to energetic and nutritional value of a diet. Other factors include determinants of family and environment, particularly eating habits and behavior, awareness of nutrition and physical activity [16].

Preventive measures for adolescents are an important priority in school systems. A few interventions have been developed, but their effectiveness varies significantly among researches [8].

In municipal schools of Greece, a system of national dietary principles was implemented, with the aim of preventing obesity among schoolchildren. This system included raising awareness of foodstuffs (vegetables, fruits, cereals, meat, fish, eggs, dairy and other products) and outreach on healthy lifestyle [17].

Based on large-scale analysis of electronic databases according to results of 27 conducted researches, including 18 in USA, it has been established that among the most common strategies, outreach works, educational materials and sessions were implemented. That being said, time spent by teachers on implementing these activities amounted to 26.6-54.9 minutes per week, while economically they were deemed viable [8].

According to results of cross-research among 413 students of secondary school of Istanbul, it has been established that behavior of adolescents regarding lifestyle and trust-based relations with close friends and family members, intensive public activity in free time promoted improvement of their life, regardless of social and demographical factors [18].

Similar conclusions have been reached in another survey of 812 Turkish secondary school students, expanding the range of predictors of healthy lifestyle behaviors, parents' education and positive self-esteem of one's own health [19].

Our research, just like provided results from global literary sources, has established the importance of developing healthy lifestyle skills with the aim of obesity prevention. However, for the first time, a possible mechanism of influence and ways for individualization of preventive measures have been established. It is an influence depending on nature of attitude of adolescents towards an educational institution and utilization of potential of school education and environment for development and implementation of individually-oriented preventive measures. 


\section{CONCLUSIONS}

Results of survey among ninth grade students regarding certain aspects of their lifestyle show substantial differences in eating behavior and physical activity, depending on attitude towards an educational institution. The most safe group as to development of obesity and other diseases have been students who attended an educational institution with pleasure. They had a high level of physical activity, have been in the open air more frequently, and had more developed rational eating habits. It is reasonable to include students with indifferent attitude towards any occupation (activity) into the risk group as to development of obesity. Their ration was characterized by insufficient amounts of key sources of protein, daily consumption of chips, crackers, street food and sparkling water.

Studying the way of life of primary school children, while taking into account social environment of a specific educational facility, including motion activity, nature of nutrition and prevalence of bad habits provides the opportunity to develop a complex, subject-oriented prevention program. Its participants should be not only students, but parents and teachers as well.

Outstanding remains the issue of in-depth study of prevalence of healthy lifestyle skills and bad habits among various sex groups of adolescents.

\section{REFERENCES}

1. Mayne S.L., Virudachalam S., Fiks A.G. Clustering of unhealthy behaviors in a nationally representative sample of U.S. children and adolescents. Prev Med. 2020 Jan;130:105892. doi: 10.1016/j.ypmed.2019.105892.

2. Martin A., Saunders D.H., Shenkin S.D. et al. Lifestyle intervention for improving school achievement in overweight or obese children and adolescents. Cochrane Database Syst Rev. 2014; 14;(3):CD009728. doi: 10.1002/14651858.CD009728.pub2.

3. Baceviciene M., Jankauskiene R., Emeljanovas A. Self-perception of physical activity and fitness is related to lower psychosomatic health symptoms in adolescents with unhealthy lifest. BMC Public Health. 2019;19: 980. doi: 10.1186/s12889-019-7311-2.

4. Shi Y., Joyce C., Wall R. et al. A life satisfaction approach to valuing the impact of health behaviours on subjective well-being. BMC Public Health. 2019;19(1):1547. doi: 10.1186/s12889-019-7896-5.

5. Hamulka J., Wadolowska L., Hoffmann M. et al. Effect of an Education Program on Nutrition Knowledge, Attitudes toward Nutrition, Diet Quality, Lifestyle, and Body Composition in Polish Teenagers. The ABC of Healthy Eating Project: Design, Protocol, and Methodology. Nutrients. 2018; 10(10). pii: E1439.doi: 10.3390/nu10101439.

6. CohenA.K.,SymeS.L. Education:amissedopportunity forpublichealth intervention. Am JPublic Health. 2013;103(6):997-1001. doi: 10.2105/AJPH.2012.300993.

7. Wolfenden L., Nathan N.K., Sutherland R. et al. Strategies for enhancing the implementation of school-based policies or practices targeting risk factors for chronic disease. Cochrane Database Syst Rev. 2017;11:CD011677. doi: 10.1002/14651858.CD011677.

8. Strøm H.K., Adolfsen F., Fossum S. et al. Effectiveness of school-based preventive interventions on adolescent alcohol use: a meta-analysis of randomized controlled trials. Subst Abuse Treat Prev Policy. 2014;9:48. doi: 10.1186/1747-597X-9-48.

9. Danylenko H.M., Podrigalo L.V., Avdiievska O.H. Hihiienichni ta medykosotsialni osoblyvosti zberezhennia zdorovia uchniv zakladiv zahalnoi serednoi osvity u suchasnii rodyni [Hygienic and medico-social features of health preservation in the schoolchildren at the institutions of secondary education in modern family]. Environment \&Health. 2019; 4: 24-30. (UA)
10. Berdnyk 0.V.,Dobrianska 0.V., Rudnytska 0.P.,SkochkoT.P.Zdorov`enaseleniya kak kriterial 'naya kharakteristika ego kachestva [The health of population as a criterial characteristic of its quality]. Environment \&Health. 2018; 1: 4-8. (Ru)

11. Wadolowska L., HamulkaJ., KowalkowskaJ. etal. Prudent-Active and Fast-FoodSedentary Dietary-Lifestyle Patterns: The Association with Adiposity, Nutrition Knowledge and SociodemographicFactorsin Polish Teenagers-The ABC of Healthy Eating Project. Nutrients. 2018; 10(12). pii: E1988. doi: 10.3390/nu10121988.

12. Teo C.H., Chin Y.S., Lim P.Y. et al. School-based intervention that integrates nutrition education and supportive healthy school food environment among Malaysian primary school children: a study protocol. BMC Public Health. 2019;19(1):1427. doi: 10.1186/s12889-019-7708-y.

13. Wadolowska L., Hamulka J., Kowalkowska J. et al. Changes in Sedentary and Active Lifestyle, Diet Quality and Body Composition Nine Months after an Education Program in Polish Students Aged 11 12 Years: Reportfrom the ABC of Healthy Eating Study. Nutrients.2019;11(2). pii:E331.doi:10.3390/nu11020331.

14. Marques A., Peralta M., Santos T. et al. Self-rated health and health-related quality of life are related with adolescents' healthy lifestyle. Public Health. 2019;170:89-94. doi: 10.1016/j.puhe.2019.02.022.

15. Day R.E., Sahota P., Christian M.S. Effective implementation of primaryschoolbased healthy lifestyle programmes: a qualitative study of views of school staff. BMC Public Health. 2019;19(1): 1239. doi: 10.1186/s12889-019-7550-2

16. Weker H., Barańska M. Models of safe nutrition of children and adolescents as a basis for prevention of obesity. Med Wieku Rozwoj. 2011;15(3):288-97.

17. Kastorini C.M., Critselis E., Zota D. et al. National Dietary Guidelines of Greece for children and adolescents: a tool for promoting healthy eating habits. Public Health Nutrition. 2019, 22 (14): 2688-2699 doi.org/10.1017/ S1368980019001034.

18. Ilhan N., Peker K., Yildirim G. et al. Relationship between healthy lifestyle behaviors and health related quality of life in turkish school-going adolescents. Niger J Clin Pract. 2019;22(12):1742-1751. doi: 10.4103/njcp.njcp_190_19.

19. ArdicA., Esin M.N. Factors AssociatedWith Healthy Lifestyle Behaviors in a Sample ofTurkishAdolescents:ASchool-Based Study.JTranscultNurs. 2016;27(6):583-592.

The research work "To study medical and social conditions for positive impact of family on preservation and strengthening of health of school-age children" (national registry № 0117U003011).

\section{ORCID and contributionship:}

Heorhii M. Danylenko - 0000-0001-7086-2720 A,B,C,D,E,F

Zhanna V.Sotnikova-Meleshkina-0000-0001-5534-8264 A,B,C,D,E,F

Vladyslav A. Smiianov - 0000-0002-4240-5968 C,E,F

\section{Conflict of interest:}

The Authors declare no conflict of interest

\section{CORRESPONDING AUTHOR \\ Zhanna V. Sotnikova-Meleshkina}

6 Svobody Sq., Kharkiv, 61022, Ukraine

tel: +380507094393

e-mail: zhanna.v.sotnikova@karazin.ua

\author{
Received: 31.01 .2020 \\ Accepted: 02.04 .2020
}

A - Work concept and design, B - Data collection and analysis, C - Responsibility for statistical analysis,

D-Writing the article, $\mathbf{E}$-Critical review, $\mathbf{F}$ - Final approval of the article 